DOI: https://doi.org/10.47405/mjssh.v5i9.488

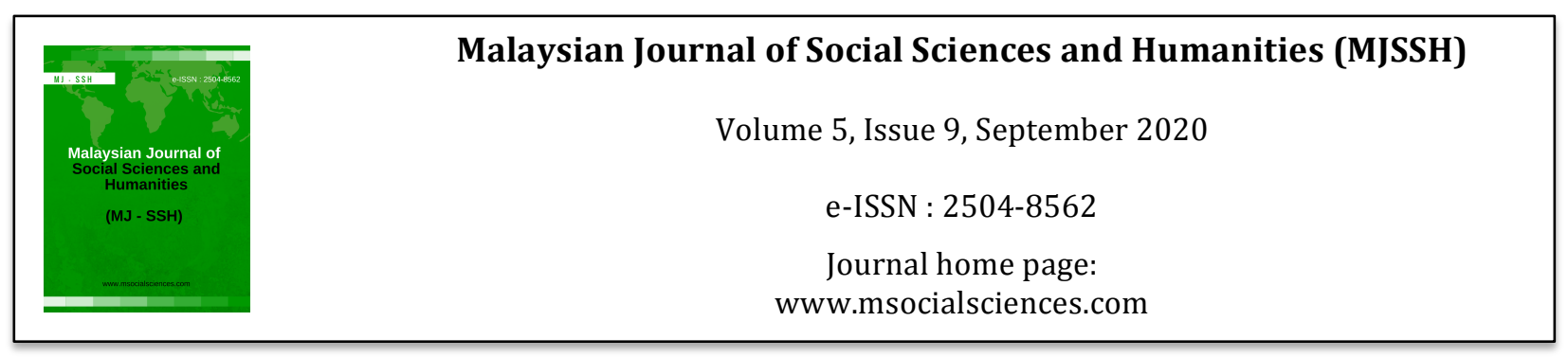

\title{
Perbandingan Dialek Jordan dengan Bahasa Arab Standard
}

\author{
Nurulasyikin Muda', Hazmi Dahlan' ${ }^{1}$ \\ 1Pusat Penataran Ilmu dan Bahasa, Universiti Malaysia Sabah (UMS) \\ Correspondence: Nurulasyikin Muda (syikin@ums.edu.my)
}

\begin{abstract}
Abstrak
Jordan merupakan sebuah negara Timur Tengah yang menggunakan bahasa Arab sebagai bahasa rasmi dan menjadi pilihan kepada para pelajar Malaysia untuk menyambung pengajian dalam bidang berbagai. Namun begitu, antara masalah yang dihadapi oleh para pelajar adalah kemahiran dan pengetahuan dialek tempatan yang diperlukan dalam komunikasi harian termasuk penggunaannya di institusi pengajian dan dalam kuliah mereka. Walaupun mereka telah belajar bahasa Arab di sekolah namun ianya tidak sama dengan dialek. Kajian ini ingin melihat ciri-ciri perbezaan antara dialek dan bahasa ini yang menggunakan kaedah tinjauan deskriptif melalui frasa-frasa dari lima buah video dari YouTube. Kelima-lima video ini merupakan video yang dihasilkan oleh Qasid Institute yang merupakan sebuah institusi pengajian bahasa Arab yang menyampaikan isi kandungan video selaras dengan hasil tinjauan pengkaji sendiri selama berada di Jordan. Kajian mendapati ciri perbezaan yang terbesar antara keduanya merangkumi perbezaan kosa kata yang merupakan ciri terpenting dalam dialek. Selain itu ciri-ciri perbezaan yang lain adalah penggabungan dua perkataan menjadi satu perkataan sahaja, penukaran baris huruf, penukaran bunyi kepada bunyi yang tidak ada dalam sistem bahasa Arab standard, pemansuhan bunyi dan juga peralihan tempat baris bagi sesuatu huruf. Terdapat juga bunyi perkataan yang sama pada keduanya namun berbeza dari konteks makna. Pemahaman berkaitan sistem dialek ini sangat penting untuk persediaan mental dan motivasi pelajar dalam kehidupan harian bermasyarakat lebih-lebih lagi untuk pelajaran mereka di Jordan. Justeru, kajian ini juga diharapkan dapat memberi gambaran terhadap kepentingan menyediakan kursus pendedahan berkaitan dialek oleh pihak berwajib.
\end{abstract}

Kata kunci: bahasa Arab, dialek Jordan, komunikasi, kosa kata, perbandingan

\section{A Comparison between Jordan Dialect and Standard Arabic Language}

\begin{abstract}
Jordan is a Middle Eastern country that uses Arabic as the official language and is an option for Malaysian students to pursue their studies in various fields. However, among the problems that students face are the skills and knowledge of the local dialect needed in daily communication, including its use in institutions of study. Although they have learned Arabic in school, it is not the same language. This study wanted to look at the differences between these dialects and languages using descriptive survey methods through the phrases of five videos from YouTube. All of the videos produced by the Qasid Institute, an Arabic language learning institution that delivers video content in line with the researchers' experience during their studying time in Jordan. This study has found that the most significant difference between the two is the difference in vocabulary, which becomes the most important feature of the dialect. Other notable features are the combination of two words into one
\end{abstract}


word, diacritical mark conversion, sound conversion to sound that is not in the standard Arabic system, abolition of sound and even the placement of mark for a letter. There is also a word which shares the same sound but different in the context of meaning. The understanding of this dialectic system is crucial to the mental preparation and motivation of students in daily community living especially for their studies in Jordan. Therefore, this study is also expected to highlight the importance of providing dialectical exposure courses by the authorities.

Keywords: Arabic language, Jordan dialect, communication, vocabulary, comparison

\section{Pengenalan}

Jordan merupakan sebuah negara yang menjadi pilihan kepada pelajar Malaysia untuk melanjutkan pelajaran dalam bidang berbagai. Selain Jordan, negara-negara Timur Tengah yang lain yang menjadi tempat mencari ilmu adalah Arab Saudi, Mesir, Syria dan Maghribi. Selain menjadi tempat untuk mencari ilmu, terdapat juga rakyat Malaysia yang berada di negara-negara ini untuk bekerja dalam bidang diplomatik, perniagaan dan petroleum. Secara umumnya negara-negara Timur Tengah secara rasminya meletakkan bahasa Arab sebagai bahasa utama dalam urusan-urusan rasmi dan menjadi penyatuan kepada negara-negara ini. Begitu juga dengan faktor agama yang dominan di mana Islam menjadi agama terbesar dianuti, yang mempunyai al Quran sebagai panduan dan dibaca menggunakan bahasa Arab atau lebih tepat lagi menggunakan bahasa Arab klasikal. Walaupun bahasa Arab telah menjadi bahasa rasmi kepada negara-negara ini, masyarakat mereka tidak terlepas dari situasi ingin memudahcara komunikasi harian mereka dan menjadikan dialek iaitu sistem pertuturan yang diambil secara majoriti dari bahasa rasmi, kemudian mengalami beberapa perubahan samada dari sudut bunyi, penyingkatan suku kata dan perkataan serta perubahan-perubahan yang lain yang dirasakan perlu, maka wujudlah sistem dialek dalam kalangan masyarakat ini.

Jordan menggunakan dialek Levantine yang merupakan dialek paling dekat dengan bahasa Arab standard (Berlitz Jordan, 2017). Antara bidang-bidang pengajian yang menjadi pilihan kepada pelajar Malaysia untuk berada di Jordan adalah bahasa Arab, syariah, perundangan, ekonomi, perubatan dan pergigian. pelajar -pelajar ini menjalani pengajian mereka dalam bahasa Arab dan dialek yang digunakan oleh pensyarah. Kajian ini merupakan kajian tinjauan deskriptif berdasarkan pengalaman pengkaji berada di Jordan selama sepuluh tahun sepanjang menjadi salah seorang pelajar Ijazah Sarjana Muda (Kepujian) Bahasa Arab dan Kesusateraan di Universiti Al al-Bayt dari 1995 sehingga 2001 dan ketika menyambung pengajian di peringkat Ijazah Kedoktoran Kurikulum dan Pengajaran di The World Islamic Science and Education University dari 2012 sehingga 2016. Sepanjang 2013 sehingga 2016 pengkaji dijemput menjadi tenaga pengajar dialek Jordan kepada para pegawai Kedutaan Malaysia di Amman, Jordan dalam memenuhi permintaan mereka untuk membantu memudahkan urusan harian dengan masyarakat setempat. Antara kewajaran lain untuk kajian ini dilaksanakan adalah memanfaatkan kemahiran pengkaji yang telah melengkapkan Kursus Jordanian Colloquial Arabic Tahap Lanjutan II pada 2015 di Ahlan Jordan, Arabic Centre di Amman, Jordan.

Kajian ini dijalankan untuk menjelaskan perbezaan antara frasa-frasa yang telah dipelajari secara formal selama berada di sekolah-sekolah di Malaysia dengan frasa-frasa yang digunakan dalam dialek.

\section{Pernyataan masalah}

Berdasarkan pengalaman pengkaji juga ketika pertama kali menjejakkan kaki di Jordan, pengkaji telah mengalami kejutan budaya dalam komunikasi di mana pengkaji tidak dapat memahami perbualanperbualan yang berlangsung malah pengkaji tidak dapat menjawab soalan-soalan yang ditanya oleh masyarakat sekitar kampus. Nik Nasri (2009) juga mempunyai pengalaman yang hampir sama dan juga dalam tempoh berbulan-bulan hanya memahami soalan-soalan yang diajukan namun tidak mampu menjawab soalan-soalan tersebut. Dialek tempatan ini mempunyai perbezaan yang ketara jika dibandingkan dengan bahasa Arab yang telah dipelajari di sekolah-sekolah di Malaysia. Dalam pengkuliahan juga, para pensyarah turut menggunakan dialek sebagai bahasa pengantara terutamanya 
dalam bidang pengajian selain Bahasa Arab. Situasi ini memperlihatkan seolah-olah bahasa Arab yang telah dipelajari di sekolah tidak begitu memberi manfaat kepada para penuntut Malaysia yang belajar di Jordan dalam kepenggunaan interaksi harian. Ini menyukarkan proses pembelajaran yang diperlukan kerana para penuntut akan mempunyai masalah untuk memahami apa yang dituturkan oleh para pensyarah dan juga rakan-rakan berbangsa Arab. Malah, ketika pengkaji mengikuti kursus persediaan ke Timur Tengah selama tiga bulan juga tidak begitu didedahkan dengan senario sebenar komunikasi dengan dialek.

\section{Persoalan Kajian}

Kajian ini mempunyai satu soalan kajian sahaja iaitu: Apakah bentuk perbezaan antara frasa dialek dan bahasa Arab standard?

\section{Kajian literatur}

Penggunaan dialek didapati berlaku pada banyak bahasa termasuklah bahasa Arab. Ferguson (1959) menyifatkan bahawa dialek Arab merujuk kepada fenomena dua bahasa berbeza dalam bahasa percakapan masyarakat yang sama yang digunakan terutamanya dalam komunikasi oleh penuturnya. Bahasa Arab standard adalah bahasa yang diguna dalam situasi rasmi manakala dialek digunakan sebagai alat komunikasi harian. Bassiouney (2010) berpandangan bahawa bahasa Arab dilihat merupakan salah satu bahasa yang terkuat menggunakan dialek. Di antara dialek-dialek Arab yang ada, dialek Mesir menjadi dialek yang paling popular kerana kebanyakan filem-filem Arab merupakan filem yang dihasilkan menggunakan dialek Mesir (Abu-Melhim, 2014). Dialek digunakan dalam komunikasi harian dan tidak diajar secara formal di sekolah. Ianya tidak mempunyai tatabahasa yang ditetapkan oleh organisasi tertentu namun masih mempunyai ciri-ciri tatabahasanya yang tersendiri. Usaha-usaha untuk memperkenalkan dan mendokumentasikan dialek telah dilihat berlaku semenjak tahun 70an sebagai usaha individu. Walaupun dialek mempunyai perbezaan dari segi sebutannya, namun selalunya dialek menggunakan huruf-huruf dalam bahasa Arab standard untuk penulisan (Zaidan \& Burch, 2014). Istilah dialek untuk bahasa Arab turut mempunyai isitlah-istilah lain dalam bahasa Arab iaitu lahjah, darijah, maHkiy, dan "ammiyyah (Setiyadi, 2011).

Secara umumnya, dialek Arab terdiri dari 5 kelompok iaitu

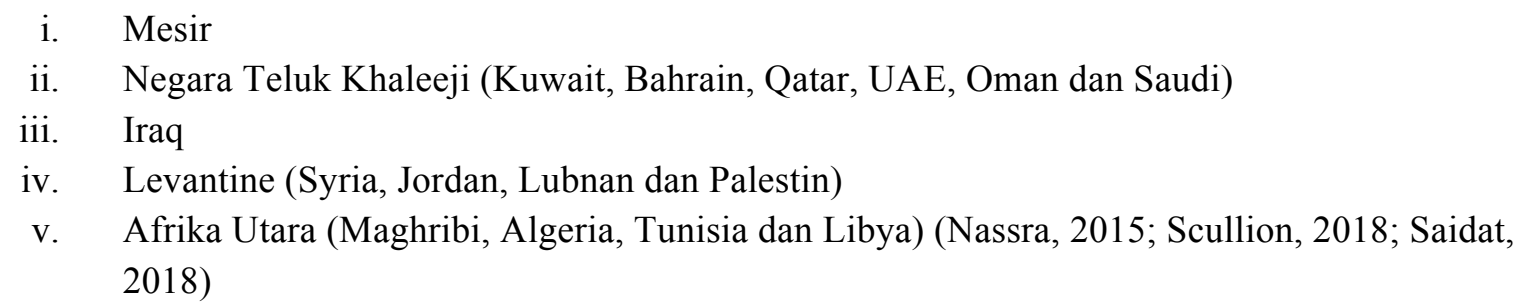

Kelompok-kelompok ini mempunyai perbezaan yang ketara antara satu kelompok dengan kelompok yang lain sehinggakan penutur sesuatu dialek juga tidak dapat memahami dialek yang berlainan. Contoh perbezaan dialek dan sebutannya boleh dilihat dari jadual di bawah yang telah dipetik dari Scullion (2018)

Jadual 1: Perbezaan Dialek Mengikut Kelompok Berbanding Bahasa Arab Standard

\begin{tabular}{lllllll} 
& Apa & Mana & Bila & Bagaimana & Mengapa & Siapa \\
\hline fusHa & maatha & ayna & mataa & kayf & limatha & man \\
\hline
\end{tabular}




\begin{tabular}{lllllll}
\hline aamiyah & eih & feen & imta & izzayy & leih & miin \\
shaami & shoo & wayn & imta & keef & leesh & meen \\
maghribi & shnoo & feen & foquash & kifash & 3lash & shkoon \\
khaleeji & maa aysh & ayn & mata & kayf & limih & man \\
\hline
\end{tabular}

Bahasa Arab standard ( $f u s H a$ ) sebagaimana yang dipelajari di sekolah-sekolah di seluruh dunia adalah lebih jelas bunyinya dan teratur susunan ayatnya. Ia menjadi bahasa perantara yang mudah tanpa melihat kepada asal penutur tersebut (Scullion, 2018). Walaupun demikian, menurut Hofmeier (2017), selain dari mengetahui bahasa Arab standard, adalah sangat penting untuk mengetahui sekurang-kurang beberapa frasa ucapan dalam dialek tempatan.

Nassra (2015) berpendapat bahawa bahasa Arab standard adalah merupakan bahasa yang diperlukan dalam mendapatkan maklumat atau memberi maklumat dalam bentuk bertulis dan secara rasmi. Ia berbeza dengan dialek Arab yang digunakan secara harian. Justeru, Nassra melihat bahasa Arab boleh dipelajari dengan dua kaedah iaitu, belajar bahasa Arab standard terlebih dahulu yang akan membolehkan pelajar mahir dengan huruf-huruf, tatabahasa dan barulah dipelajari dialeknya. Ini adalah merupakan kaedah pilihan yang dilaksanakan di kebanyakan universiti di United Kingdom. Kaedah kedua pula menjadi pilihan bagi Nassra sendiri iaitu mempelajari dialek terlebih dahulu dan barulah belajar bahasa Arab standard kerana kaedah ini adalah lebih natural di mana kanak-kanak berbangsa Arab berkomunikasi dengan ahli keluarga menggunakan dialek mereka yang telah dipelajari secara mendengar dalam bentuk spontan semenjak lahir. Kemudiannya, barulah mereka mendapatkan pendidikan secara formal dan mempelajari bahasa Arab standard. Selain itu, kaedah ini dilihat dapat membantu pelajar-pelajar yang mempunyai keperluan dan keinginan untuk berkomunikasi secara berkesan dalam kehidupan seharian mereka serta berpeluang untuk belajar bahasa dengan lebih cepat melalui keyakinan dan kemampuan mereka untuk berkomunikasi kerana ramai pelajar yang belajar bahasa Arab hilang semangat dan tidak minat untuk meneruskan pembelajaran dengan baik sekiranya mereka terlalu memfokuskan kepada bahasa Arab standard yang mengurangkan peluang untuk berkomunikasi.

Promadi (2015) menyatakan bahawa terdapat juga satu bentuk percakapan Arab yang digunakan oleh golongan terpelajar yang menggabungkan antara Bahasa Arab standard dan juga dialek dalam perbualan harian mereka. Justeru, keadaan ini memperlihatkan bahawa, dalam konunikasi harian sebagai pelajar di Jordan, pengetahuan berkaitan dialek adalah sangat penting.

Palmer (2007) melihat situasi pendedahan pelajar yang belajar bahasa Arab standard kepada dialek boleh melindungi pelajar dari silap faham, rasa malu dan rendah diri, rasa pelik dan kecewa apabila berinteraksi dengan penutur jati Arab apatah lagi mereka juga mendapati rakan-rakan berbangsa Arab yang tergolong dalam ahli masyarakat yang berpendidikan tinggi juga mempunyai kesukaran untuk menggunakan bahasa Arab standard sepenuhnya dalam perbualan dan perbincangan (Kaye, 2001; Bassiouney, 2010). Justeru, keadaan ini boleh memberi kesan sedikit sebanyak kepada motivasi pelajar untuk belajar bahasa dan subjek-subjek bidang mereka (Fogel \& Ehri, 2000). Menurut Lambert (1990) kesan kepada motivasi dalam kes ini yang disebut sebagai bilingualism, boleh menjadi additive dan subtracttive. Ada pelajar yang mengalami motivasi additive dengan menjadikan bahasa kedua atau dialek bagi bahasa berkenaan bernilai tambah kepada kemampuan berbahasa sedia ada tanpa takut kehilangan kemahiran dalam bahasa pertama atau bahasa asal kepada dialek berkenaan. Berbeza dengan pelajar yang mengalami motivasi subtractive, mereka menjadi keliru dan takut akan menjadi semakin tidak mahir dengan bahasa pertama atau bahasa asal kepada dialek.

Dalam konteks langkah penyediaan para pelajar untuk melanjutkan pelajaran ke Timur Tengah, kursuskursus disediakan dan di akhir kursus tersebut akan diberikan sijil tahap penguasaan kemahiran 
berbahasa Arab yang meliputi mendengar, bertutur, membaca dan menulis. Kursus ini adalah melalui hebahan yang dibuat oleh Kementerian Pelajaran Malaysia (permohonan.my, 2017). Dalam tahun yang lain pula sebagaimana yang telah direkodkan dalam video yang dimuat naik di YouTube (Fatihah, 2019), Pusat Kecemerlangan Pedagogi Bahasa Arab Kementerian Pendidikan Malaysia telah sekali lagi menganjurkan kursus serupa. Dalam video berkenaan, terdapat sedikit pendedahan dialek penutur asal pada minit ke 2:07, namun sepanjang persembahan video berkenaan menunjukkan kursus lebih berfokus menggunakan bahasa Arab Standard dalam semua kemahiran yang diajar.

Selain itu, terdapat juga program (Program Belajar Bahasa Arab Ana Arabiy Jordan, Mekah, Madinah \& Turkey, 2015) yang menawarkan kursus bahasa Arab kepada bakal pelajar ke TImur Tengah yang mensasarkan kelebihan kursus di mana pelajar akan mendapat sekurang-kurangnya empat perkara; ulangkaji dan faham semua tajuk-tajuk penting dalam bahasa Arab; latihan bercakap Arab sepanjang program; pendedahan peperiksaan kelayakan atau dikenali "Imtihan Qabul" yang melibatkan empat hingga lapan set soalan klon yang digunakan meliputi aspek karangan, mendengar, temubual, menulis, serta soalan-soalan berkaitan tatabahasa dan lain-lain; dan persiapan ilmu, maklumat, mental dan fizikal untuk ke IPT dan Timur Tengah. Walau bagaimana pun, program ini tidak menjelaskan penggunaan dialek dalam kemahiran yang bakal diajar.

Melihat kepada pengalaman beberapa pelajar Malaysia yang terpaksa menghadapi penduduk tempatan untuk urusan harian mereka terutamanya ketika membeli keperluan di pasar menyifatkan mereka banyak mempelajari kosa kata dari pergaulan mereka dengan penduduk tempatan dan keyakinan untuk berkomunikasi ini telah menambahkan motivasi untuk belajar bahasa Arab (Bernama, 2018) Sementara itu, Saidat (2018) menyatakan bahawa terdapat perkembangan perubahan dialek secara berterusan mengikut rentak pilihan generasi pada satu-satu masa. Pendedahan kepada dialek-dialek yang hampir sama dari kawasan-kawasan jiran yang boleh didengari atau diadaptasi secara fizikal mahupun maya yang tidak dinafikan bersesuaian dengan arus kepesatan teknologi di hujung jari menjadikan generasi ini memilih apa yang lebih mudah, sedap didengar, mudah disebut dan yang mempunyai budaya menarik. Generasi ini juga berpandangan dengan memberi peluang kepada perubahan dialek ini menunjukkan bahawa mereka adalah masyarakat yang terbuka dan cakna kepada masyarakat lain selain ianya boleh melambangkan tahap pemikiran global.

Qatar Foundation International (2019) yang merupakan salah sebuah institusi mengajar Bahasa Arab dengan memfokuskan kepada komunikasi, menerapkan unsur-unsur kelas interaktif, berpusat pelajar dan juga berfikir kritis menegaskan bahawa pembelajaran mestilah bersifat berkait dengan dunia sebenar di sekitar mereka. Justeru, mereka menggalakkan Bahasa Arab standard dan dialek diajar serentak di bilik darjah memandangkan penutur-penutur Arab di negara-negara Arab menggunakan dialek dalam pertuturan harian mereka. Dalam menjawab persoalan adakah pengajaran Bahasa Arab dan dialek ini perlu diajar serentak atau bergilir-gilir atau secara berasingan, Promadi (2016) menyatakan bahawa ianya bukan sesuatu yang mudah untuk dilaksanakan pengajarannya serentak kerana kekeliruan mungkin akan timbul terutamanya menggunakan perkataan atau ayat dialek dalam penulisan formal. Namun begitu sekiranya ianya dijalankan secara berasingan, ianya akan mengalami pembaziran masa kerana akan memerlukan pengulangan bahan pengajaran yang sama dalam bahasa Arab standard terutamanya bagi perkataan dan tatabahasa. Oleh yang demikian, beliau mencadangkan bahawa penggabungan antara bahasa Arab standard dan dialek yang disebut sebagai bahasa percakapan Arab golongan terpelajar diketengahkan lebih awal sebelum kemahiran lain dalam bahasa Arab yang menggunakan bahasa Arab standard. Ini kerana, walaupun di negara Arab sendiri yang merupakan tempat asal bahasa Arab, namun adalah amat penting untuk kita menyedari realiti penggunaan bahasa Arab standard tidak digunakan dalam komunikasi harian walaupun dalam industri pengajaran bahasa Arab sebagai bahasa asing. Oleh yang demikian adalah dijangkakan konsep bahasa percakapan Arab golongan terpelajar ini juga sedang dalam perhatian para sarjana untuk diperbincangkan dan dibuat kajian-kajian yang berkaitan.

Dari sudut kajian lepas berkaitan dialek Arab, didapati sangat sedikit kajian dijalankan untuk membuat perbandingan di antara bahasa Arab standard dengan dialek Jordan. Terdapat juga beberapa kajian yang menyentuh tentang dialek Arab namun kebanyakannya melihat kepada situasi masyarakat dan perkembangan dialek serta kesannya kepada para pelajar yang belajar bahasa Arab sebagai bahasa pertama dan bahasa kedua dan bukan menjurus kepada perbezaan antara bahasa Arab dan dialek. 
Terdapat juga kajian lepas yang berkaitan perbandingan dialek dengan bahasa rasmi masyarakat yang lain seperti bahasa Melayu dan bahasa Jerman namun penulis hanya ingin memfokuskan kepada kajiankajian yang di dalam skop perbandingan bahasa Arab dengan dialek sahaja.

Antara kajian yang mempunyai sedikit perkaitan adalah yang ditulis oleh Alif Cahaya (2011) yang mengkaji tentang perbezaan-perbezaan secara geografi dan sosial sesuatu masyarakat dan bagaimana perbezaan-perbezaan secara fonologi, morfologi dan sintaksis untuk bahasa Arab keseluruhannya dan mendapati bahawa terdapat beberapa huruf konsonan khusus yang dianggap berat dan mengalami perubahan untuk dilembutkan bunyinya.

Laila 2018 dalam kajiannya untuk mensintesis maklumat tentang perkembangan dialek Arab mendapati bahawa dalam membanding frasa antara bahasa Arab standard dan dialek, kluster konsonan ataupun dua konsonan tidak digabungkan bersama dalam bahasa Aab standard tetapi wujud penggunaannya dengan banyak dalam dialek. Dapatan lain juga adalah hujung perkataan bahasa Arab standard boleh terdiri dari dua konsonan tetapi jarang pula diguna dalam dialek yang menjadikan peletakan vowel di antara dua konsonan tadi. Dalam sistem fonologi, terdapat perbezaan bunyi frasa namun dianggap tidak menjadi masalah yang besar dengan dapat mengecam bunyi seakan dari bahasa Arab standard. Yang menjadi masalah utama dalam kedua keadaan ini adalah yang berkaitan dengan perkataan atau kosa kata, perubahan bunyi pada huruf seperti "q" menjadi “"”. Perubahan perkataan ini adalah disebabkan oleh pertembungan bahasa Arab dengan negara-negara luar yang mengalami penaklukan Islam yang mana kebanyakannya terkesan dengan bahasa-bahasa yang berasal dari Parsi, Iraq, Turki dan Greek di Syria yang akhirnya membentuk perkataan-perkataan baru menjadi dialek mengikut kedudukan geografi. Adalah dijangkakan perubahan dalam dialek akan terus berlaku mengikut arus perkembangan dan pertembungan budaya semasa.

\section{Metodologi Kajian}

Pengkaji telah mendapati beberapa video yang memberi penerangan tentang penggunaan dialek Jordan namun pengkaji telah mendapati sebuah saluran youtube sebanyak lima video yang memberi penerangan berkaitan frasa-frasa dialek ringkas bersifat survival yang perlu diketahui oleh bukan Arab yang kelihatan lebih tersusun dan formal dalam teknik penyampaiannya dihasilkan oleh sebuah institusi pengajian di Jordan, iaitu Qasid Arabic Institute. Berdasarkan video-video penerangan ini, pengkaji akan membuat perbandingan frasa berkenaan dengan frasa dalam bahasa Arab standard. Hasil dari perbandingan akan disenaraikan ciri-ciri perbezaannya dalam dapatan kajian ini. Video-video berkenaan adalah:

\footnotetext{
i. Survival Arabic: Lesson 01 - Greetings

ii. Survival Arabic: Lesson 02 - Introductions

iii. Survival Arabic: Lesson 03 - Taxis \& Directions

iv. Survival Arabic: Lesson 04 - At the Restaurant

v. Survival Arabic: Lesson 05 - Money \& Currency
}

Perbualan dalam bentuk ayat lengkap yang berlangsung dalam kesemua video berkenaan tidak termasuk dalam skop kajian ini.

Dalam menulis transliterasi bagi perkataan-perkataan Arab, terdapat banyak sistem yang telah dibina. Namun, penulis telah membina sistem jadual transliterasi yang lebih mesra penaipan untuk digunapakai dalam penulisan kajian ini seperti jadual di bawah.

Jadual 2: Jadual Transliterasi

\section{Huruf Arab}

$\sqrt{ } / 1$
Transliterasi

a 


\begin{tabular}{|c|c|}
\hline ب & $\mathrm{b}$ \\
\hline$ت$ & $\mathrm{t}$ \\
\hline$ث$ & th \\
\hline 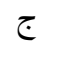 & $\mathrm{j}$ \\
\hline$\tau$ & $\mathrm{H}$ \\
\hline$\dot{\tau}$ & $\mathrm{kh}$ \\
\hline د & $\mathrm{d}$ \\
\hline$\dot{~}$ & $\mathrm{dz}$ \\
\hline J & $\mathrm{r}$ \\
\hline j & $\mathrm{z}$ \\
\hline س & $\mathrm{s}$ \\
\hline ش & sh \\
\hline ص ص & $\mathrm{S}$ \\
\hline ض & $\mathrm{D}$ \\
\hline b & $\mathrm{T}$ \\
\hline ظ & $\mathrm{Z}$ \\
\hline$\varepsilon$ & “ \\
\hline$\dot{\varepsilon}$ & gh \\
\hline ف & $\mathrm{f}$ \\
\hline ق & $\mathrm{q}$ \\
\hline ك & $\mathrm{k}$ \\
\hline J & 1 \\
\hline r & $\mathrm{m}$ \\
\hline ن & $\mathrm{n}$ \\
\hline و & $\mathrm{w}($ konsonan) $\mathrm{u}($ vowel) \\
\hline 。 & $\mathrm{h}$ \\
\hline$c$ & ‘ \\
\hline ي & y(konsonan) i(vowel) \\
\hline
\end{tabular}




\section{Dapatan kajian}

Dapatan kajian ini menyenaraikan setiap frasa yang mempunyai perbezaan di antara dialek Jordan dan bahasa Arab standard yang diterjemahkan dalam jadual di bawah. Setiap frasa disertakan dengan transliterasi untuk menerangkan kaedah sebutan sebenar bagi kedua-dua jenis frasa berkenaan. Frasafrasa ini disenaraikan mengikut susunannya dalam video berkenaan serta mengikut urutan nombor dari video 1 sehingga video 5. Setiap penerangan yang melibatkan huruf akan ditulis dengan huruf dalam bahasa Arab manakala yang melibatkan bunyi akan ditulis dengan huruf roman iaitu mengikut kaedah transliterasi.

Jadual 3: Perbezaan Bunyi antara Dialek dan Bahasa Arab Standard

\begin{tabular}{|c|c|c|c|}
\hline & Dialek & Standard & Perbezaan \\
\hline 1 & أهلا وسهلا & أهلا وسهلا & -penghapusan bunyi " $n$ " dari alif tanwin \\
\hline 2 & marHaba & marHaban & -penghapusan bunyi " $n$ " dari alif tanwin \\
\hline 3 & مرحبتين & marHaban & 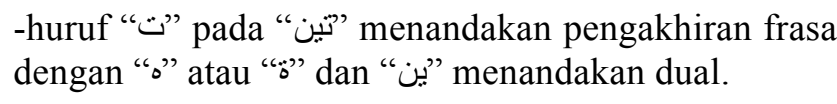 \\
\hline 4 & kiifak / kiifek & كيف أنت & $\begin{array}{l}\text {-penggabungan dua perkataan menjadi satu } \\
\text {-perkataan "أن" ditukar menjadi" "ك" "fa" menjadi "fe" } \\
\text {-sebutan "fa" }\end{array}$ \\
\hline 5 & $\begin{array}{l}\quad \text { كويس(ة) } \\
\text { kuweiyyes } \\
\text { kuweiyseh }\end{array}$ & $\begin{array}{l}\text { jayyid } \\
\text { jayyidah }\end{array}$ & -perkataan yang berbeza \\
\hline 6 & $\begin{array}{l}\text { meniiH } \\
\text { meniiHeh }\end{array}$ & $\begin{array}{l}\text { jayyid } \\
\text { jayyidah }\end{array}$ & -perkataan yang berbeza \\
\hline 7 & shu & $\begin{array}{l}\text { maa } \\
\text { maadzaa }\end{array}$ & -perkataan yang berbeza \\
\hline 8 & $\begin{array}{l}\text { أخبارك akhbaarak } \\
\text { akhbaarek }\end{array}$ & $\begin{array}{l}\text { akhbaaruka } \\
\text { akhbaaruki }\end{array}$ & $\begin{array}{l}\text {-penukaran tempat fatHah dan kasrah pada huruf " "ك" "J" } \\
\text { kepada huruf" } \\
\text {-huruf "كilang baris dan menjadi sukun }\end{array}$ \\
\hline 9 & $\begin{array}{l}\text { بشوفك } \\
\text { bshuufak } \\
\text { bshuufek }\end{array}$ & $\begin{array}{l}\text { naraaka } \\
\text { naraaki }\end{array}$ & -perkataan yang berbeza \\
\hline 10 & يلا باي & مع السلامة & -perkataan yang berbeza \\
\hline 11 & $\begin{array}{l}\text { ismak } \\
\text { ismek }\end{array}$ & $\begin{array}{l}\text { ismuka } \\
\text { ismuki }\end{array}$ & -penukaran tempat fatHah dan kasrah pada huruf “" "ك" \\
\hline
\end{tabular}




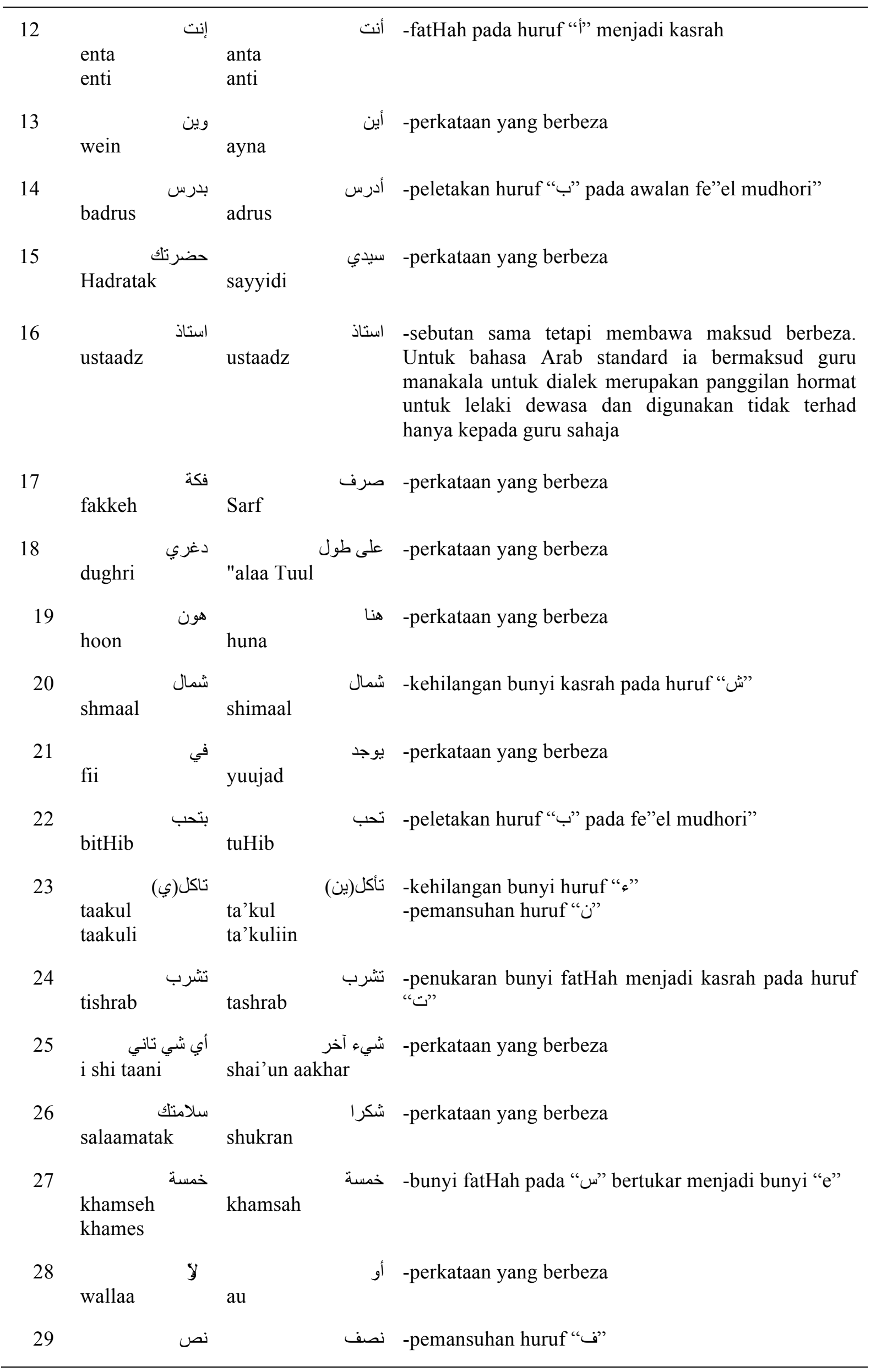




\begin{tabular}{|c|c|c|c|c|c|}
\hline & nuS & & niSfu & & \\
\hline \multirow[t]{2}{*}{30} & & قِيّش & & كم & -perkataan yang berbeza \\
\hline & addeesh & & kam & & \\
\hline \multirow[t]{2}{*}{31} & & قرش & & قرش & -penukaran bunyi “q” kepada ““، \\
\hline & irsh & & qirsh & & \\
\hline \multirow[t]{2}{*}{32} & & عشرة & & عشرة & -penukaran fatHah kepada sukun pada huruf “ش” \\
\hline & "ashreh & & "asharah" & & -bunyi fathah pada " $\jmath$ " bertukar menjadi bunyi "e" \\
\hline \multirow[t]{2}{*}{33} & & 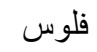 & & نقود & -perkataan yang berbeza \\
\hline & fuluus & & nuquud & & \\
\hline \multirow[t]{2}{*}{34} & & 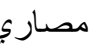 & & نقود & -perkataan yang berbeza \\
\hline & maSaari & & nuquud & & \\
\hline \multirow[t]{2}{*}{35} & & لبّي & & 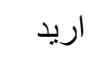 & -perkataan yang berbeza \\
\hline & biddii & & uriidu & & \\
\hline
\end{tabular}

Dari 35 frasa yang telah dianalisis bentuk perbezaannya, sebanyak 14 ciri perbezaan telah direkodkan dan diperincikan bentuk perbezaannya serta nombor frasa yang berkaitan dalam jadual di bawah.

Jadual 4: Ciri Perbezaan antara Dialek dan bahasa Arab Standard

\begin{tabular}{lll}
\hline & Ciri Perbezaan & Nombor Frasa \\
\hline 1 & Perbezaan perkataan & $5,6,7,9,10,13,15,17,18,19,21$, \\
& & $25,26,28,30,33,34,35$ \\
2 & Bunyi fatHah menjadi "e" & 27,32 \\
3 & Bunyi “q” menjadi “"” & 31 \\
4 & Pemansuhan huruf & 23,29 \\
5 & Gabung beberapa perkataan menjadi satu & 4 \\
6 & Penukaran baris huruf & $4,8,12,32$ \\
7 & Hilang bunyi “"” & 23 \\
8 & Tambahan huruf "ب" pada fe"el mudhaari” & 14,22 \\
9 & Hilang bunyi baris pada huruf & 20 \\
10 & Perkataan sama namun maksud berbeza & 16 \\
11 & Penambahan huruf "ta” & 3 \\
12 & Penggunaan dual sebagai respon & 3 \\
13 & Baris beralih tempat & 8,11 \\
14 & $\begin{array}{l}\text { Penukaran kata ganti nama berpisah menjadi } \\
\text { bersambung }\end{array}$ & 4 \\
\hline
\end{tabular}




\section{Perbincangan Dapatan Kajian}

Penggunaan perkataan yang tersendiri dan berbeza dengan bahasa Arab standard adalah memberi gambaran bahawa masyarakat Jordan telah membentuk perkataan khusus bersesuaian dengan masyarakat mereka yang telah terkesan dari berbagai faktor sosial seperti yang dinyatakan oleh Saidat (2018). Secara umumnya kajian ini mendapati perbezaan perkataan menjadi ciri utama dalam perbezaan antara dialek dan bahasa Arab standard iaitu berlaku kepada sebanyak 18 frasa jika ingin dibandingkan dengan kekerapan berikutnya iaitu sebanyak 4 frasa sahaja yang berciri bertukar baris huruf. Ciri perbezaan kosa kata yang ketara ini menyokong dapatan Laila (2018) yang mendapati wujudnya perkataan baru sebagai dialek yang berbeza dengan bahasa Arab standard. Ini menunjukkan dialek Jordan perlu diketahui kosa katanya yang khusus kerana ianya mempunyai peranan utama dalam komunikasi dengan dialek.

Untuk itu, pengetahuan asas yang telah dipelajari di sekolah tidak begitu memainkan peranan dalam mendapatkan kosa kata dalam komunikasi harian. Ianya cuma mungkin dapat dimanfaatkan pada frasafrasa yang mengalami penukaran bunyi fatHah kepada "e", "q" kepada “"”, seperti dapatan Laila (2018) yang mendapati wujud perkataan dialek yang mengalami perubahan bunyi "q" kepada bunyi “"”, penukaran baris huruf, hilang bunyi "“" dan baris beralih tempat kerana ciri-ciri ini masih mengekalkan tulisan yang sama dan cuma mengalami sedikit perbezaan bunyi baris yang masih mudah diagak. Perubahan-perubahan ini juga berlaku sebagaimana yang dinyatakan oleh Alif (2011) dan Saidat (2018) untuk memudahkan lidah menuturkan perkataan. Dapatan lain yang tidak ada sumber untuk dibandingkan dengan kajian-kajian lepas merangkumi; (i) ciri penggabungan beberapa perkataan menjadi satu, (ii) perbezaan makna pada perkataan yang sama; (iii) serta penambahan huruf-huruf seperti "ب" dan "“" yang boleh menimbulkan kekeliruan kepada pelajar memandangkan ianya tidak wujud dalam sistem tatabahasa dalam bahasa Arab standard. Sekiranya para pelajar mempunyai asas bahasa Arab yang kukuh, ia boleh menjadikan pendedahan dan pengetahuan kepada dialek ini sebagai nilai tambah kepada kemahiran berbahasa dan berkomunikai mereka.

\section{Kesimpulan}

Kesimpulan dari kajian ini mendapati bahawa bahasa Arab merupakan bahasa yang mempunyai keunikan tersendiri dengan mempunyai dialek yang melibatkan perbezaan kosa kata sebagai elemen utama. Kosa kata ini terhasil dari pertembungan budaya untuk memudahkan komunikasi harian malah turut digunakan oleh golongan terpelajar dalam situasi pembelajaran rasmi. Sebagai seorang pelajar bukan penutur jati Arab yang hanya belajar bahasa Arab standard, perbezaan kosa kata ini tidak terdapat dalam isi kandungan pelajaran mereka di sekolah dan tidak dibukukan sebagai bahan rujukan. Keadaan ini sudah pasti menimbulkan kekeliruan kepada mereka apabila berkomunikasi dengan penutur jati Arab khususnya di Jordan samada dalam menjalankan urusan harian dan juga ketika belajar di dalam kuliah serta sewaktu melakukan perbincangan dengan rakan-rakan Arab.

Justeru, antara pendedahan penting yang perlu dilaksanakan kepada para pelajar yang ingin menyambung pelajaran ke Jordan ialah memberikan pengetahuan dialek Jordan melalui kursus-kursus yang bersesuaian. Ini kerana ianya boleh memudahkan proses pembelajaran disebabkan oleh persediaan pelajar tentang pengetahuan kosa kata asas dan pemahaman terhadap bentuk perubahan-perubahan yang berlaku di antara dialek dan bahasa Arab standard. Pengetahuan dan pemahaman ini boleh menghindarkan ketakutan dan kekeliruan dalam berkomunikasi sekaligus akan memudahkan komunikasi mereka bersama rakan-rakan Arab, para pengajar serta anggota masyarakat. Keperluan kemahiran ini tidak memberi maksud bahawa pelajar akan melupakan bahasa Arab standard namun sekiranya penambahan kemahiran dialek ini dikuasai, ia akan boleh membantu pelajar untuk lebih yakin berkomunikasi dalam menambahkan ilmu pengetahuan dalam bidang masing-masing serta bakal menjadi pencetus untuk belajar dengan lebih seronok. 


\section{Rujukan}

Abu-Melhim, A. (2014). INtra-lingual code alternation in Arabic: the conversational impact of diglossia. Theory and Practice in Language Studies, 4(5), 891-902

Alif Cahaya Setiyadi. (2011). Dialek Bahasa Arab Tinjauan Dialektologis. Jurnal At-Ta'dib, 6(1), 127-146.

Al-Batal, Mahmoud (2017). Dialect Integration in the Arabic Foreign Language Curriculum: Vision, Rationales and Models. Arabic as One Language: Integrating Dialect in the Arabic Language Curriculum. Al-Batal, Mahmoud (ed). Washington University Press, Washington DC (pp 1-15)

Bassiouney, R., (2010). Redefining Identity Through Code Choice in Al-Hubb Fi al-Manfa by Baha' Tahir. Journal of Arabic and Islamic Studies, 10(5), 101-118.

Berlitz Jordan. (2017) The Best Cities in the Middle East to Study Arabic. Retrieved from http://berlitz-jo.com/about/who-we-are/blog/199-best-cities-study-arabic

Bernama. (2018). Belajar bahasa Arab di 'pasar' Jordan sangat berkesan. Retrieved from https://www.freemalaysiatoday.com/category/bahasa/fmt-ohsem/2018/08/08/belajar-bahasa-arabdi-pasar-jordan-sangat-berkesan/

Fatihah Safie. (2019) Kursus Persediaan Pelajar Ke Timur Tengah (Isti'dadi) Ambilan Ogos 2019 (kohort ke-5). Retrieved from https://www.youtube.com/watch?v=zk1wrB0qzwQ

Hofmeier, Sara. (2017). Greetings and replies in different Arabic dialects. Retrieved from https://arabiconline.eu/greetings-replies-different-arabic-dialects/

Kaye, A.S., (2001). Diglossia: the state of the art. International Journal of Social Language, 152, 117 129.

Kursus Bahasa Arab Persediaan ke IPT \& Timur Tengah. (2015). Program Belajar Bahasa Arab Ana Arabiy Jordan, Mekah, Madinah \& Turkey. Retrieved from https://msmy.facebook.com/AnaArabiy/posts/kursus-bahasa-arab-persediaan-ke-ipt-timur-tengahmasihberbaki-13-kekosongkandaf/413645745464172/

Laila Abdullah Al Suwaiyan. (2018). Diglossia in the Arabic Language. International Journal of Language and Linguistics, 5(3), 228-238.

Nassra, Omar. (2015). The Difference Between Modern Standard Arabic and its Dialects Retrieved from http://www.londonarabictuition.com/blog/arabic-language/difference-modern-standardarabic-dialects/

Nik Nasri. (2009). Kembara Ilmu 5:Masuk Fakulti Syariah, Univ Yarmouk guna SPM sains Retrieved from http://www.niknasri.com/?p=1858

Palmer, J.L. (2007). Arabic Diaglossia: Teaching only the standard variety is a disservice to students. Arizona Working papers in Second Language Acquisition and Teaching, 14, 111-122.

Permohonan.my. (2017). Permohonan Kursus Persediaan Pelajar ke TImur Tengah. Retrieved from https://www.permohonan.my/permohonan-kursus-persediaan-pelajar-ke-timur-tengah/

Promadi Karim. (2016). Educated Spoken Arabic (ESA): A New Alternative for future teaching Arabic as a Foreign Language. Journal of Education and Social Sciences, Vol 4. (June) 26-32.

Qatar Foundation International. (2019) Retrieved from https://www.qfi.org/for-teachers/teacherresources/arabic-communicative-classroom/

Saidat, Am. (2018). Jordanian Arabic: A Study of the Motivations for the Intentionally in Dialect Change. Theory and Practice in Language Studies, 8(6), 580-587

Scullion, S. (2018) Arabic dialects across the Arab World. Retrieved from https://arabiconline.eu/arabic-dialects-across-arab-world/

Zaidan, Omar F. \& Bursh, C.C. (2014). Arabic Dialect Identification. Computational Linguistic, 40(1), 171-202. 